
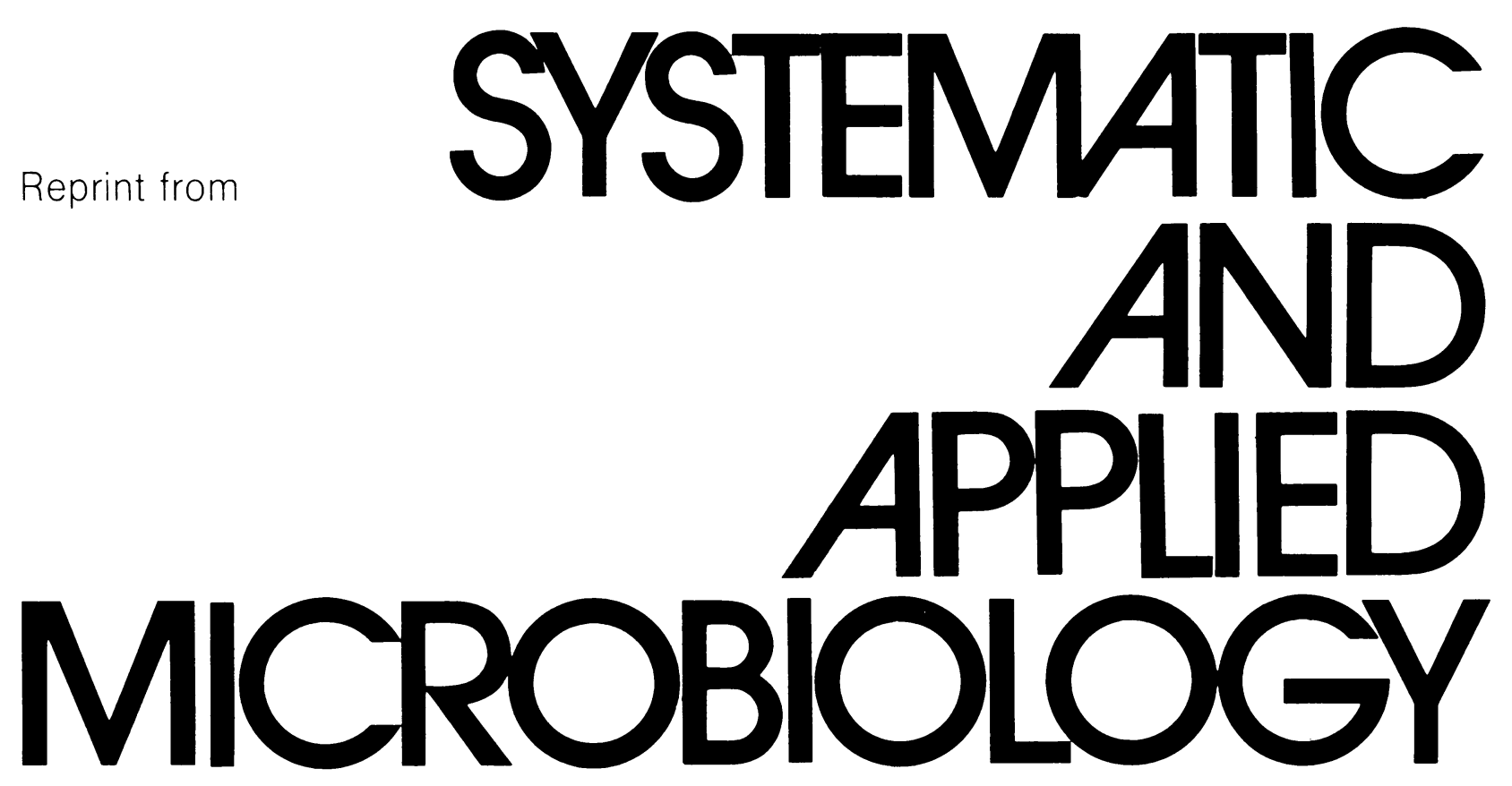

formerly Zentralblatt für Bakteriologie,

Mikrobiologie und Hygiene

I. Abt. Originale C

Gustav Fischer Verlag

Stuttgart - New York 



\title{
Affinity Labelling of the Active Center of DNA-dependent RNA Polymerases within the Archaebacterial Kingdom
}

\author{
MICHAEL THOMM ${ }^{1}$, ANTON J. LINDNER ${ }^{2}$, GUIDO R. HARTMANN ${ }^{2}$, and K. O. STETTER ${ }^{1}$ \\ 1 Lehrstuhl für Mikrobiologie, Universität Regensburg, D-8400 Regensburg, Federal Republic of Germany \\ 2 Institut für Biochemie der Universität München, D-8000 München 2, Federal Republic of Germany
}

Received September 1, 1987

\begin{abstract}
Summary
The super-selective affinity labelling procedure for the active center of RNA polymerase from Escherichia coli (Grachev et al., 1987a) was successfully applied to the enzyme from archaebacteria. Using adenosine5'-trimetaphosphate or the p-hydroxybenzaldehyde ester of ATP, the second largest subunit B' of the RNA polymerase from methanogenic/halophilic and sulphate reducing archaebacteria, and the largest subunit B of the non-methanogenic thermophilic archaebacterium Sulfolobus sp. strain B 12 are labelled specifically. The labelling reaction is strictly template-dependent and blocked by the transcription inhibitor heparin. We present evidence that adenosine- 5 '-trimetaphosphate is attached close to the catalytic center of the RNA polymerase via a phosphoamide bond to lys or his residues.

The specific affinity labelling of subunit $B^{\prime}$ from methanogens/halophiles together with the earlier observed immunological cross-reactivity (Gropp et al., 1986) indicates that this subunit as well as subunit $B^{\prime \prime}$ contains amino acid sequences which are homologous to sequences in subunit B of the enzyme from non-methanogenic thermophilic archaebacteria and in subunit $\beta$ from $E$. coli RNA polymerase.
\end{abstract}

Key words: Archaebacteria - RNA polymerase - Catalytic center - Affinity labelling - Evolution

\section{Introduction}

The isolated RNA polymerases from archaebacteria have been shown to consist of 8-10 polypeptide chains (Zillig et al., 1985a). In their polypeptide pattern and in their antigenicity (Huet et al., 1983; Gropp et al., 1986) these enzymes resemble much more the eukaryotic RNA polymerases $\mathrm{A}, \mathrm{B}$ and $\mathrm{C}$ than the RNA polymerase of Escherichia coli. To three of the four subunits $\beta^{\prime}, \beta, \alpha$ and $\sigma$ of the E. coli enzyme some functions could be assigned, e.g. to subunit $\beta^{\prime}$ affinity to DNA, to subunit $\beta$ the participation in rifampicin-binding and to subunit $\sigma$ the promoter recognition (for review see Yura and Ishibama, 1979). In archaebacteria, the fifth largest polypeptide $E$ of the Halobacterium halobium and of Thermoplasma acidophilum RNA polymerase has been reported to be required for transcription of natural DNA templates and to be dispensable for transcription of the synthetic template poly d(A-T) (Madon and Zillig, 1983; Schnabel et al., 1982). Up to now no further information is available

Abbrevations: ATmP, Adenosine-5'-trimetaphosphate, ATP-A, 4-Hydroxybenzaldehyde ester of ATP on the role of the various polypeptides contained in purified archaebacterial RNA polymerases. The fact that the four largest components of these enzymes could be allied with each other by serological cross-reaction (Schnabel et al., 1983; Thomm et al., 1986) indicates that at least these polypeptides are necessary for the function of archaebacterial RNA polymerases. Immunological analyses revealed distinct differences in the RNA polymerase structure between different groups of archaebacteria (Schnabel et al., 1983). The RNA polymerases of methanogenic/halophilic archaebacteria contain two polypeptides $B^{\prime}$ and $B^{\prime \prime}$, which both show serological crossreaction to the largest subunit $B$ of the enzymes from nonmethanogenic thermophilic archaebacteria. According to this feature the $A B^{\prime} B^{\prime \prime}$-C-type of methanogens/halophiles and the BAC-RNA polymerase type of non-methanogenic thermophiles can be distinguished (Zillig et al., 1985a). The RNA polymerase of the recently discovered sulphate reducing archaebacterium "Archaeoglobus fulgidus" (Stetter et al., 1987) harbours two polypeptides homologous to $\mathrm{B}^{\prime}$ and $\mathrm{B}^{\prime \prime}$ of methanogens/halophiles. In contrast 
to all other archaebacteria containing this enzyme, the immunological determinants of the first (A) and fourth (C) component are present in one polypeptide $\left((\mathrm{A}+\mathrm{C}) \mathrm{B}^{\prime} \mathrm{B}^{\prime \prime}\right.$ type; Stetter et al., 1987).

Recently, by "super-selective affinity labelling" the second largest subunit of the E. coli (Grachev et al., 1987a) and of the three RNA polymerases, A, B and C from yeast (Riva et al., 1987) have been shown to participate in the formation of the active center. Using the same method we identified in this study the subunit of three different types of archaebacterial RNA polymerases which carry the active center.

\section{Materials and Methods}

\section{Purification of RNA polymerases}

RNA polymerases of methanogenic bacteria, Halobacterium and Sulfolobus sp. strain B 12 were purified as decribed previously (for review see Thomm et al., 1986; Zillig et al., 1985a).

\section{Synthesis of the reactive ATP derivatives}

Adenosine-5'-trimetaphosphate (ATmP) and the p-hydroxybenzaldehyde ester of ATP (ATP-A) were synthesized as described by Knorre et al. (1976) and Grachev et al. (1987a), respectively.

\section{Affinity labelling of RNA polymerases}

Archaebacterial RNA polymerases were modified by cyclic adenosine-5'-trimetaphosphate $(\mathrm{ATmP})$ or the p-hydroxybenzaldehyde ester of ATP (ATP-A) in a reaction mixture $(10 \mu \mathrm{l}$ ) containing $11 \mathrm{mM}$ HEPES, $\mathrm{pH} 7.9,10 \mathrm{mM} \mathrm{MgCl}_{2}$, and 2-5 $\mu \mathrm{g}$ RNA polymerase in the presence of the salt concentration optimal for each enzyme (Thomm et al., 1986; Zillig et al., 1985a). The final concentrations of the derivatives were $1.5 \mathrm{mM}$ and 1 $\mathrm{mM}$, respectively $\left(5 \mathrm{~min}\right.$ incubation at $37^{\circ} \mathrm{C}$. In experiments with ATP-A, $1 \mu \mathrm{l}$ of a $\mathrm{NaBH}_{4}$ solution $(5 \mathrm{mg} / \mathrm{ml})$ was added after the modification reaction to reduce the double-bond of the Schiffbase and the excess of the derivative, and incubation continued for $20 \mathrm{~min}$ at $0^{\circ} \mathrm{C}$. The modification with ATmP was performed for $25 \mathrm{~min}$ at $37^{\circ} \mathrm{C}$. After the addition of $1 \mu \mathrm{l}$ poly $\mathrm{d}(\mathrm{A}-\mathrm{T})(1$ $\mathrm{mg} / \mathrm{ml})$ and $1 \mu \mathrm{l}\left[\alpha^{32} \mathrm{P}\right] \mathrm{UTP}(3000 \mathrm{Ci} / \mathrm{mmol})$ a phosphodiester bond is formed between an enzyme-linked derivative close to the catalytic center and UTP during $20 \mathrm{~min}$ at the transcription temperature optimal for each enzyme (Thomm et al., 1986; Zillig et al., 1985a). To remove the radioactive RNA which could be formed by unmodified RNA polymerase the reaction mixture was treated with pancreatic RNase A $\left(10 \mu \mathrm{g} / \mathrm{ml} ; 15 \min 37^{\circ} \mathrm{C}\right)$. To degrade the template poly $\mathrm{d}(\mathrm{A}-\mathrm{T})$, also pancreatic DNase $(3$ $\mu \mathrm{g} / \mathrm{ml}$ ), was added. After the RNase- and DNase-treatment the reaction was stopped with electrophoresis sample buffer as described previously (Grachev et al., 1986). The RNA polymerase subunits were separated electrophoretically in 5-25 percent exponential polyacrylamide gels in the presence of $\mathrm{Na}$-dodecylsulfate (Thomm et al., 1986). The Coomassie-Blue stained gels were dried and labelled polypeptides identified by autoradiography at $-70^{\circ} \mathrm{C}$ intensified by Dupont Cronex Quanta II screen.

Isolation of the labelled dinucleotide ApU from the B subunit of Methanococcus vannielii

B' subunit from $20 \mu \mathrm{g}$ Mc. vannielii RNA polymerase was isolated after affinity labelling with ATmP by electroelution from an unstained polyacrylamide gel employing a Biotrap BT 1000 apparatus (Schleicher \& Schüll) (Jacobs and Clad, 1986). The eluted protein was precipitated with 4 volumes of acetone, dissolved in $180 \mu \mathrm{H} \mathrm{H}_{2} \mathrm{O}$ and acidified to $50 \mathrm{mM} \mathrm{HCl}$. After $1 \mathrm{~h}$ at $37^{\circ} \mathrm{C}$ the $\mathrm{pH}$ was adjusted to 8.0 with tris-base, 2 units of calf intestinal alkaline phosphatase (Boehringer, Mannheim) were added and the mixture incubated $1 \mathrm{~h}$ at $37^{\circ} \mathrm{C}$. The solution was then dried in vacuo and the pellet redissolved in $5 \mu$ l of water. Comparison of the labelled compound with an ApU standard (Sigma, Taufkirchen) was performed by chromatography on polyethyleneiminecellulose-foils (Merck), Kieselgel $60 \mathrm{~F}_{254}$ thin layer plates (Merck) or Whatman $3 \mathrm{MM}$ chromatography paper. The solvents used were $0.16 \mathrm{M} \mathrm{LiCl}$ or $0.5 \mathrm{M}$ sodium formate $\mathrm{pH}$ 3.6 (PEI-cellulose), isopropanol : $25 \% \mathrm{NH}_{3}: \mathrm{H}_{2} \mathrm{O}=6: 3: 1$ (kieselgel thin layer plates) and $0.1 \mathrm{M}$ sodium phosphate $(\mathrm{pH}$ 6.8) : $\left(\mathrm{NH}_{4}\right)_{2} \mathrm{SO}_{4}:$ n-propanol $=100: 60: 2$ (3 MM paper) (Randerath and Randerath, 1967; Hanna and Meares, 1983; Bock et al., 1956).

\section{Results \\ Affinity labelling of RNA polymerases}

In order to localize the active center on the subunits of archaebacterial RNA polymerases, the enzymes were modified with ATmP or ATP-A. After synthesis of labelled dinucleotides (Grachev, et al., 1986; see also Materials and Methods) the polypeptides of the RNA polymerases were separated by polyacrylamide gel electrophoresis in presence of dodecylsulphate and polypeptides containing covalently bound radioactive compounds identified by autoradiography. As a representative of the $A^{\prime} B^{\prime \prime} C$ RNA polymerase type, the enzymes from $M c$. vannielii, Methanococcus thermolithotrophicus, Methanobacterium

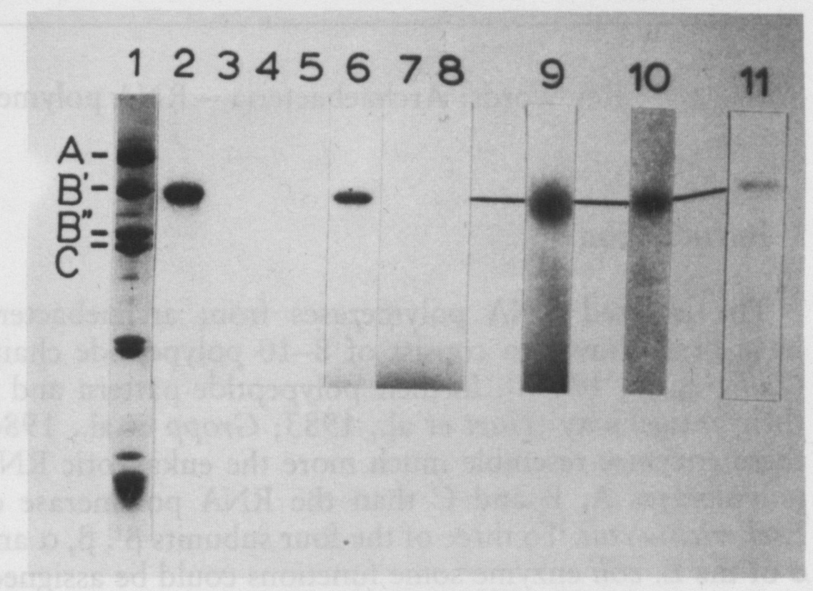

Fig. 1. Affinity labelling of the RNA polymerases from methanogenic/halophilic archaebacteria.

Polypeptides were separated after affinity labelling by SDS polyacrylamide gel electrophoresis and polypeptides associated with radioactivity identified by autoradiography. Lane 1 , RNA polymerase of Methanococcus vannielii stained with Coomassie-Blue; lanes 2-8, autoradiogram of the affinity labelled Mc. vannielii RNA polymerase modified with ATP-A (lanes 2-5) and ATmP (lanes 6-8); lanes 3 and 7, without DNA template; lanes 4 and 8 in the presence of $100 \mu \mathrm{g}$ heparin $/ \mathrm{ml}$ (added immediately after the enzyme); lane 5, addition of $\mathrm{NaBH}_{4}$ omitted; lane 9-11, RNA polymerase from Mc. thermolithotrophicus, Methanobacterium thermoautotrophicum, strain W, and Halobacterium halobium labelled with ATP-A as reactive nucleotide. 
thermoautotrophicum, strain W and Halobacterium halobium were investigated. In the enzyme from Mc. vannielii only one labelled protein band was detected with both ATP-A and ATmP as reactive ATP analogue (Fig. 1, lanes 2 and 6). By comparison of the autoradiogram with the stained polyacrylamide gel (Fig. 1, lane 1), this subunit was identified as $\mathrm{B}^{\prime}$. In the absence of DNA (Fig. 1, lanes 3 and 7) and in the presence of the transcription inhibitor heparin (Fig. 1, lanes 4 and 8) no labelling occurred. These findings indicate that the modification of this subunit is dependent on conditions allowing initiation of RNA synthesis. As expected binding of ATP-A was unstable without addition of $\mathrm{NaBH}_{4}$ and no radioactivity could be detected (Fig. 1, lane 5). With the enzymes from Mc. thermolithotrophicus and $M b$. thermoautotrophicum W containing a subunit $\mathrm{B}^{\prime}$ of approximately the same size as Mc. vaniellii, the same polypeptide became labelled with ATP-A (Fig. 1, lanes 9 and 10) and with ATmP (data not shown). The same observation was made with the enzyme from $H$. halobium, where subunit $\mathrm{B}^{\prime}$ is about $8 \%$ larger than that of Mc. thermolithotrophicus (Fig. 1, lane 11).

In the archaebacterial sulphate-reducer (Stetter et al., 1987), which shows the $(A+C) B^{\prime} B^{\prime \prime}$ RNA polymerase type, also subunit $\mathrm{B}^{\prime}$ was labelled both with ATP-A (Fig. 2, lanes 1 and 2) and ATmP (data not shown). The controls clearly show that also with this enzyme, labelling only occurs when the affinity reagent is bound to the polypeptide in a stable form (Fig. 2, lane 4) and when the conditions of a template dependent initiation of RNA synthesis are fulfilled (Fig. 2, lane 3). Again labelling is prevented by heparin (Fig. 2, lane 5).

To localize the active center on the polypeptides of the RNA polymerases from thermophilic non-methanogenic archaebacteria (BAC-type), the enzyme of Sulfolobus sp.

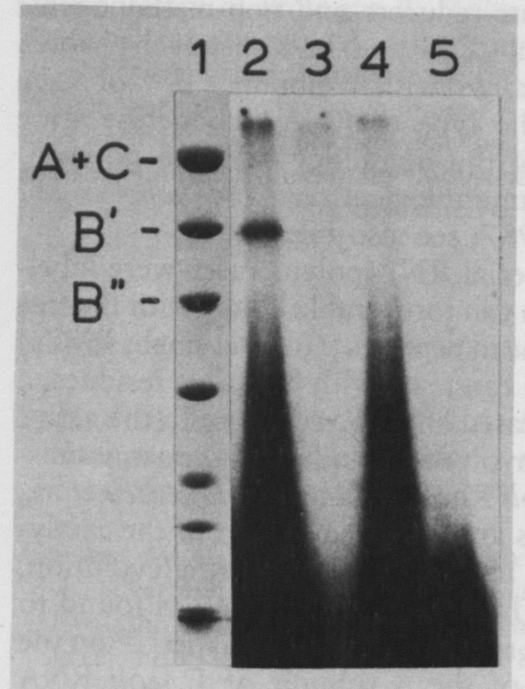

Fig. 2. Affinity labelling of the RNA polymerase from the archaebacterial sulfate reducer.

Lane 1, stained RNA polymerase (Stetter, et al., 1987; lane 2-5 autoradiography of enzyme labelled with ATP-A; lane 3 without DNA; lane 4 reduction step with $\mathrm{NaBH}_{4}$ omitted; lane 5 , in the presence of $100 \mu \mathrm{g}$ reparin $/ \mathrm{ml}$. strain B 12 was used for affinity labelling experiments. Treatment with ATmP (Fig. 3, lane 2) or ATP-A (Fig. 3, lane 5) resulted in specific labelling of the largest subunit B (Fig. 3, lane 1). The same was found with the enzyme from Sulfolobus acidocaldarius (data not shown). The corresponding controls (Fig. 3, lanes 3, 4 and 6-8) showed again that labelling was dependent on conditions appropriate for in vitro initiation of RNA synthesis.

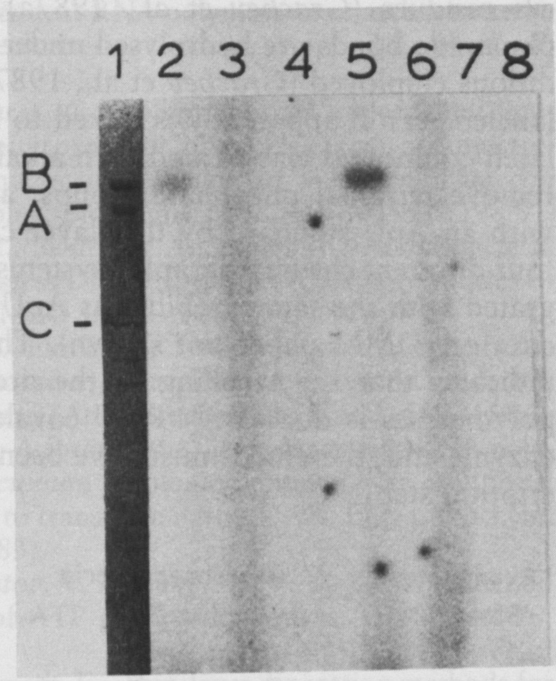

Fig. 3. Affinity labelling of the RNA polymerase from Sulfolobus sp. strain B 12 .

Lane 1 , stained RNA polymerase; lanes $2-4$, autoradiographies of enzyme affinity labelled with ATmP, lanes 5-8 with ATP-A; lanes 3 and 6, without DNA; lanes 4 and 8, in the presence of 100 $\mu \mathrm{g}$ heparin/ml; lane 7 , addition of $\mathrm{NaBH}_{4}$ omitted.

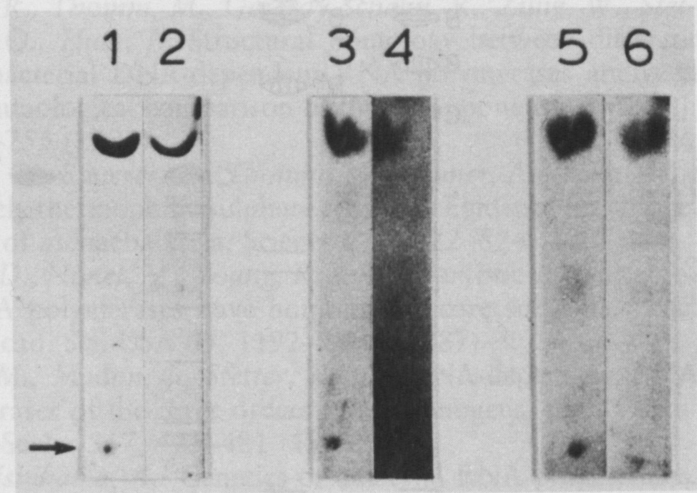

Fig. 4. Thin layer chromatography of the labelled product isolated from polypeptide $\mathrm{B}^{\prime}$ of $\mathrm{Mc}$. vannielii.

The labelled compound released from the isolated subunit $\mathrm{B}^{\prime}$ of the $M c$. vannielii RNA polymerase by mild $\mathrm{HCl}$ treatment was mixed with unlabelled ApU standard and subjected to chromatography on kieselgel thin-layer plates (lanes 1 and 2), and polyethyleneimine-cellulose (lanes 3-6) with sodium formate (lanes 3 and 4) and $\mathrm{LiCl}$ (lanes 5 and 6) as solvent. Unlabelled ApU was visualized by its UV fluorescence quenching (lanes 2, 4 and 6), the radioactive compound by autoradiography (lanes 1,3 and 5). The arrow indicates the start. 
To provide evidence that labelling of archaebacterial RNA polymerases occurs by covalently linked $\mathrm{pppA}\left[{ }^{32} \mathrm{P}\right] \mathrm{U}$ we isolated the labelled compound attached covalently to the polypeptide. After affinity labelling with ATmP as the modifying derivative and $\left[\alpha^{-32} \mathrm{P}\right] \mathrm{UTP}$, the $\mathrm{B}^{\prime}$ subunit of Mc. vannielii was isolated from a polyacrylamide gel. The labelled compound was released from the polypeptide by mild acid hydrolysis $\left(50 \mathrm{mM} \mathrm{HCl} ; 1 \mathrm{~h} 37^{\circ} \mathrm{C}\right)$. In principle ATmP can form stable bonds with lys, his, ser, thr, tyr and cys residues (Grachev et al., 1987a). Since only phosphoamide bonds are hydrolysed under the mild acid conditions employed (Grachev et al., 1987a), the radioactive labeled ATmP apparently is linked to lys or his. The isolated compound was treated with alkaline phosphatase to remove terminal phosphate groups, and then compared with an ApU standard by thin-layer chromatography. In four different chromatographic systems the compound migrated with the same mobility as ApU (Fig. 4, lanes 1-6; data on $3 \mathrm{MM}$ paper not shown). This finding strongly indicates that the labelling of the archaebacterial RNA polymerases is due to $\mathrm{A}\left[{ }^{32} \mathrm{P}\right] \mathrm{pU}$ covalently bound to the enzyme and, therefore, must have been formed in a transcription step.

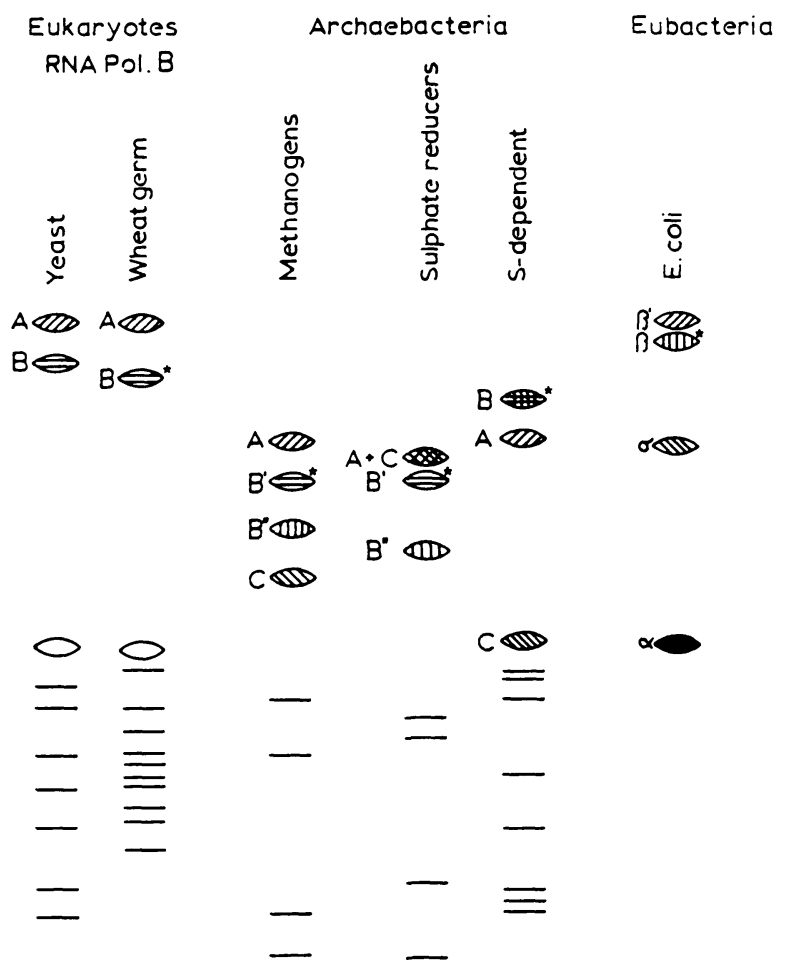

Fig. 5. Schematic representation of the subunit structure of the RNA polymerases from representatives of the three kingdoms of life.

Polypeptides which show serological cross-reaction are characterized by equivalent distinguishing marks. In the meantime, also subunit B from the yeast RNA polymerases has been shown to harbour the catalytic center (Riva et al., 1987). Note that subunit $B$ of sulfur-dependent archaebacteria contains the determinants of $B^{\prime}$ and $B^{\prime \prime}$ of methanogens and the sulphate reducer (Stetter et al., 1987). Polypeptides which have been shown to participate in the formation of the active center are indicated by an asterisk.

\section{Discussion}

The results reported above clearly demonstrate that the affinity labelling method for the active center of $E$. coli RNA polymerase developed by Grachev et al. (1987a) may also be applied to the archaebacterial RNA polymerases. The finding of a specific labelling of phage T7 RNA polymerase (Grachev et al., 1987c) consisting of a single polypeptide chain, of the three RNA polymerases A, B and $C$ from yeast (Riva et al., 1987) and of wheat germ RNA polymerase B (Grachev et al., 1986) consisting of numerous polypeptides, suggests that this procedure can generally be applied for the identification of the polypeptides and a particular region thereof involved in the organisation of the active center of all DNA-dependent RNA polymerases. Its convenient application and its high specificity recommends it for comparative studies in systematics and evolution. Interestingly, the enzymatic activity of all RNA polymerases studied so far survived the covalent attachment of the affinity label at or close to the active center and also the rather harsh treatment of the enzyme with $\mathrm{NaBH}_{4}$ for the reduction of the Schiff-base. Otherwise the labelling would not occur since it requires the enzymatic activity for the formation of the phosphodiester bond. Similar to eukaryotic RNA polymerases (Grachev et al., 1986; Riva et al., 1987) archaebacterial RNA polymerases become labelled by this procedure at only a single polypeptide. This is in contrast to the labelling of some eubacterial RNA polymerases such as the enzyme from $E$. coli where in addition to subunit $\beta$ subunit sigma also becomes labelled although only weakly (Grachev et al., 1987a).

The specific labelling of the $B^{\prime}$ subunit of RNA polymerases from four representatives of the methanogenicl halophilic type of enzyme clearly indicates that this subunit forms an essential part of the active center. In the archaebacterial sulphate-reducers and non-methanogenic thermophiles the subunits $B^{\prime}$ and $B$, respectively, which cross-react serologically with subunit $B^{\prime}$ of the methanogenic/halophilic type of RNA polymerase were labelled, corroborating the homology of these polypeptides inferred from immunological data (Schnabel et al., 1983; Stetter et al., 1987; see also Fig. 5).

Since all archaebacterial RNA polymerases were labelled with ATP-A, which can form stable bonds with the free $\epsilon$-amino group of lysine in peptides (Grachev et al., 1987a) and with ATmP which can react with lys or his residues, a lys residue must be located at least very close to the active center. Lysine is also involved in binding of the same substrate analogue to E. coli RNA polymerase (Grachev et al., 1987a). Therefore, this amino acid as a part of the catalytic center, seems to be highly conserved during evolution. Recently the attached labelled dinucleotide was found to be localized within the region from ile ${ }^{1036}$ to met ${ }^{1066}$ on the amino acid sequence of the $\beta$ subunit of $E$. coli RNA polymerase (Grachev et al., 1987b). This region contains an amino acid sequence (from leu ${ }^{1047}$ to $\arg ^{1058}$ ) which is strongly homologous to the region from leu ${ }^{961}$ to $\mathrm{lys}^{972}$ in the second largest subunit of yeast RNA polymerase B (Sweetser et al., 1987). It is this subunit which becomes labelled when the method of affinity labelling used here is 
applied to the yeast B enzyme (Riva et al., 1987). When inspecting these homologous amino acid sequences (Sweetser et al., 1987) it becomes evident that they can be folded into an $\alpha$-helix which is rich in basic amino acids on one side, a property which should be an advantage for the binding of negatively charged nucleotide residues in the active center of RNA polymerases. We would expect the conservation of homologous regions also in the $\mathrm{B}^{\prime}$ or $\mathrm{B}$ subunits of archaebacteria. Indeed, subunit $B^{\prime}$ of the methanogenic/halophilic enzyme which participates in the formation of the active center (Fig. 1) serologically crossreacts with the second largest subunit of eukaryotic RNA polymerases (Gropp et al., 1986; see schematic representation in Fig. 5) indicating an homology in functional and antigenic structure with the second largest subunit of eukaryotic RNA polymerases.

Since the archaebacterial subunit B" also shows homology with subunit $\beta$ from $E$. coli as is indicated by serological cross-reaction (Gropp et al., 1986; Fig. 5) both subunits $B^{\prime}$ and $B^{\prime \prime}$ obviously correspond to different parts of subunit $\beta$ from $E$. coli. Our findings are in contrast to the suggestion that the eubacterial subunit $\beta$ may have evolved from an RNA polymerase of the $A B^{\prime} B^{\prime \prime} C$ type by the loss of subunit $B^{\prime}$ (Zillig et al., 1985b). The subunit $B$ of non-methanogenic thermophiles and $\beta$ from $E$. coli RNA polymerase share the feature that they contain important regions of $\mathrm{B}^{\prime}$ and $\mathrm{B}^{\prime \prime}$ in one polypeptide. This may be considered as an indication that eubacterial RNA polymerases are phylogenetically more related to the enzymes from non-methanogenic thermophiles than to those from methanogens/halophiles.

Acknowledgement. Highly purified RNA polymerase preparations from Halobacterium halobium and Sulfolobus sp. strain B 12 were generously provided by F. Gropp and W.-D. Reiter from the laboratory of Professor W. Zillig, Max-Planck-Institut für Biochemie, Martinsried. A. J. L. wishes to thank F. Gropp and W.-D. Reiter for helpful advice for the assay and purification of these enzymes. The investigations of A. J. L. and G. R. H. were supported by the Deutsche Forschungsgemeinschaft (SFB 304) and the Fonds der Chemischen Industrie, the studies of M. T. and K. O. S. by grants of the Deutsche Forschungsgemeinschaft.

\section{References}

Bock, R. M., Ling, S. N., Morell, S. A., Lipton, S. M.: Ultraviolett absorption spectra of adenosine-5'-triphosphate and related 5'-ribonucleotides. Arch. Biochem. Biophys. 62, 253-264 (1956)

Grachev, M. A., Hartmann, G. R., Maximova, T. G. Mustaev, A. A., Schäffner, A. R., Sieber, H., Zaychikov, E. F.: Highly selective affinity labelling of RNA polymerase B (II) from wheat germ. FEBS Lett. 200, 287-290 (1986)

Grachev, M. A., Kolocheva, T. I., Lukhtanov, E. A., Mustaev, A. A.: Studies on the functional topography of the Escherichia coli RNA polymerase. Highly selective affinity labelling by analogous of initiation substrates. Eur. J. Biochem. 163, 113-121 (1987a)
Grachev, M. A., Lukhtanov, E. A., Mustaev, A. A., Richter, V. A., Rabinov, I. V., Skoblov, Yu. S., Abdukayumov, N. N.: Localisation of the lysine residues nearby the site of initiating substrate binding of E. coli RNA polymerase. Bioorg. Khim. 13, 552-555 (1987b)

Grachev, M. A., Zaychikov, E. F., Lukbtanov, E. A., Maximova, T. G., Mustaev, A. A.: Highly selective affinity labelling of T7 phage RNA polymerase. Bioorg. Khim. 13, 568-570 (1987c)

Gropp, F., Reiter, W. D., Sentenac, A., Zillig, W., Schnabel, R., Thomm, M., Stetter, K. O., Huet, J.: Homologies of components of DNA-dependent RNA polymerases of archaebacteria, eukaryotes and eubacteria. System. Appl. Microbiol. 7, 95-101 (1986)

Hanna, M. M., Meares, C. F.: Synthesis of a cleavable dinucleotide photoaffinity probe of ribonucleic acid polymerase: application to trinucleotide labeling of an Escherichia coli transcription complex. Biochemistry 22, 3546-3551 (1983)

Huet, J., Schnabel, R., Sentenac, A., Zillig, W.: Archaebacteria and eukaryotes possess DNA-dependent RNA polymerases of a common type. EMBO J. 2, 1291-1294 (1983)

Jacobs, E., Glad, C.: Elution of fixed and stained membrane proteins from preparative dodecyl sulfate-polyacrylamide gels into a membrane trap. Anal. Biochem. 154, 583-589 (1986)

Madon, J., Zillig, W.: A form of the DNA-dependent RNA polymerase of Halobacterium halobium containing an additional component is able to transcribe native DNA. Eur. J. Biochem. 133, 471-474 (1983)

Knorre, D. G., Kurbatov, V. A., Samikov, V. V.: General method for the synthesis of ATP gamma-derivatives. FEBS Lett. 70, 105-108 (1976)

Randerath, K., Randerath, E.: Thin-layer separation methods for nucleic acid derivatives. Meth. Enzymol. 12A, 323-347 (1967)

Riva, M., Schäffner, A. R., Sentenac, A., Hartmann, G. R., Mustaev, A. A., Zaychikov, E. F., Grachev, M. A.: Active site labelling of RNA polymerases A, B and C from yeast. J. Biol. Chem. 262, 14377-14380 (1987)

Schnabel, R., Zillig, W., Schnabel, H.: Component E of the DNA-dependent RNA polymerase of the archaebacterium Thermoplasma acidophilum is required for the transcription of native DNA. Eur. J. Biochem. 129, 473-477 (1982)

Schnabel, R., Thomm, M., Gerardy-Schahn, R., Zillig, W., Stetter, K. O., Huet, J.: Structural homology between different archaebacterial DNA-dependent RNA polymerases analyzed by immunological comparison of their components. EMBO J. 2, 751-755 (1983)

Stetter, K. O., Lauerer, G., Thomm, M., Neuner, A.: Isolation of extremely thermophilic sulphate reducers. Evidence for a novel branch of archaebacteria. Science 236, 822-824 (1987)

Sweetser, D., Nonet, M., Young, R. A.: Prokaryotic and eukaryotic RNA polymerases have homologous core subunits. Proc. Natl. Acad. Sci. USA 84, 1192-1196 (1987)

Thomm, M., Madon, J., Stetter, K. O.: DNA-dependent RNA polymerases of the three orders of methanogens. Biol. Chem. Hoppe-Seyler 367, 473-481 (1986)

Yura, T. Ishihama, A.: Genetics of bacterial RNA polymerases. Annu. Rev. Genet. 13, 59-97 (1979)

Zillig, W., Stetter, K. O., Schnabel, R., Thomm, M.: DNA-dependent RNA polymerases of the archaebacteria. In: The Bacteria, Vol. VIII, Archaebacteria (C. R. Woese, R. S. Wolfe, eds.), pp. 499-521. New York, Academic Press 1985a

Zillig, W., Schnabel, R., Stetter, K. O., Thomm, M., Gropp, F., Reiter, W. D.: The evolution of the transcription apparatus. In: Evolution of prokaryotes (K. H. Schleifer, E. Stackebrandt, eds.), pp. 45-71. New York, Academic Press 1985b 


\title{
A Comparative Study of the Amylolytic Ability of Lipomyces and Schwanniomyces Yeast Species
}

\author{
CHARLES H. HORN, ANDRÉ DE KOCK, JAMES C. DU PREEZ*, and PIETER M. LATEGAN
}

Department of Microbiology, University of the Orange Free State, Bloemfontein, South Africa

Received March 24, 1987

\begin{abstract}
Summary
The starch degrading ability of the yeast genera Lipomyces and Schwanniomyces were evaluated on solid and in liquid media. Strains of Lipomyces kononenkoae, L. starkeyi and Schwanniomyces occidentalis utilized $100 \%$ of the starch supplied, with biomass yield coefficients of up to 0.52 . There was little correlation between the clearing zone diameters on starch agar plates and the extracellular amylase activities. A derepressed mutant strain of $L$. kononenkoae had the highest $\alpha$-amylase activity (more than three-fold higher than the other yeasts) and glucoamylase activity (more than five-fold higher), while $L$. starkeyi exhibited the highest debranching activity. Furthermore, the L. kononenkoae mutant was the only yeast insensitive to glucose repression of its amylases.
\end{abstract}

Key words: Lipomyces - Schwanniomyces - Starch - Amylolytic yeast - Amylase - $\alpha$-Amylase Glucoamylase - Pullulanase

\section{Introduction}

Of the approximately 400 yeast species currently recognized, about a hundred are capable of utilizing starch as carbon and energy source (Spencer-Martins and Van Uden, 1977). Most of the amylolytic yeasts are unable to totally hydrolyze starch, however. Only a few species, therefore, show any promise for the direct bioconversion of starch to single cell protein.

Of the considerable research in recent years on starch degrading yeasts and on the bioconversion of starchy substrates to ethanol or yeast protein, relatively few studies were concerned with the differential biosynthesis of $\alpha$ amylase, glucoamylase and debranching enzymes. A few yeasts have been reported to possess all three these enzymes, including Saccharomycopsis fibuligera (Lemmel et al., 1980; Touzi et al., 1982; Ueda and Saha, 1982; De Mot et al., 1984), Lipomyces kononenkoae (Van Uden et al., 1980; Sá-Correia and Van Uden, 1981; Estrela et al., 1982; De Mot et al., 1984), Lipomyces starkeyi (Touzi et al., 1982; De Mot et al., 1984; Kelly et al., 1985) and Schwanniomyces occidentalis (Oteng-Gyang et al., 1980; Wilson and Ingledew, 1982; Touzi et al., 1982; Sills and Stewart, 1982; De Mot et al., 1984).

* Corresponding author.
The data presented in the literature do not permit a direct comparison of the starch degrading capacity of amylolytic yeasts because (i) several different amylase assays are in use, (ii) different parameters for amylolytic activity have been employed, (iii) few reports include data on all three types of amylolytic enzymes, and (iv) different media and cultivation conditions have been used. In this investigation the amylase activities, glucose catabolite repression of the amylases, the effect of growth temperature on starch hydrolysis and the growth parameters of amylolytic yeasts, selected on the basis of the published values of their amylase activities and biomass yields (SpencerMartins and Van Uden, 1977; Spencer-Martins and Van Uden, 1979; Sills and Stewart, 1982; Dhawale and Ingledew, 1983; De Mot et al., 1984), were quantitated under standardized conditions to facilitate a comparative evaluation.

\section{Materials and Methods}

Microorganisms. The strains of Lipomyces and Schwanniomyces used are listed in Table 1 . Those denoted by the code IGC were kindly supplied by Prof. N. van Uden, Gulbenkian Institute 